Journal of Educational Technology

\& Online Learning

Volume 3 | Issue 2 | 2020

http://dergipark.gov.tr/jetol

\title{
Book Review: Blockchain Technology Applications in Education
}

Aylin Ceylan ${ }^{\mathrm{a}}$

a aylinceylan@anadolu.edu.tr; Anadolu University, Eskişehir, Turkey; ORCID: 0000-0002-5539-7442

Doi: 10.31681 jetol.698498

Suggested citation: Ceylan, A. (2020). Book Review: Blockchain Technology Applications in Education. Journal of Educational Technology \& Online Learning, 3(2), 168-176.

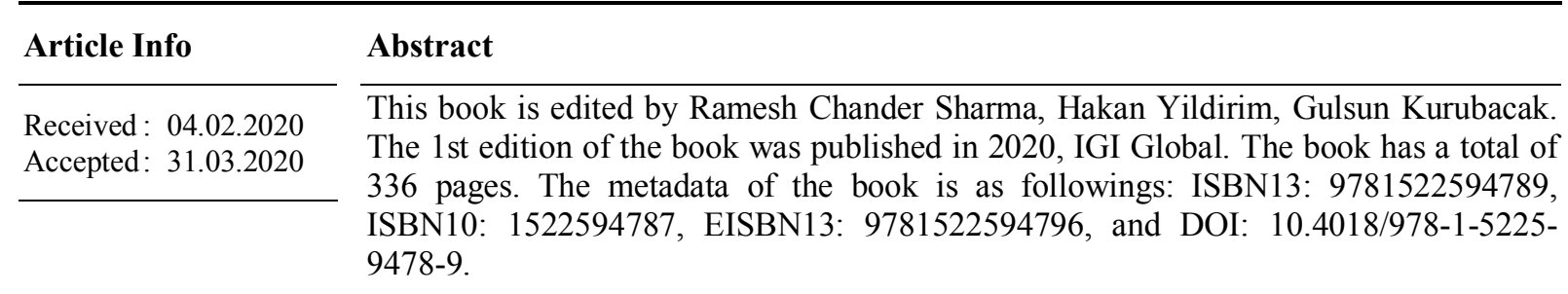

Book Review Keywords: Blockchain, lifelong learning, higher education, distance education, digital transformation.

\section{INTRODUCTION}

Premier Reference Source

Blockchain Technology

Applications in Education

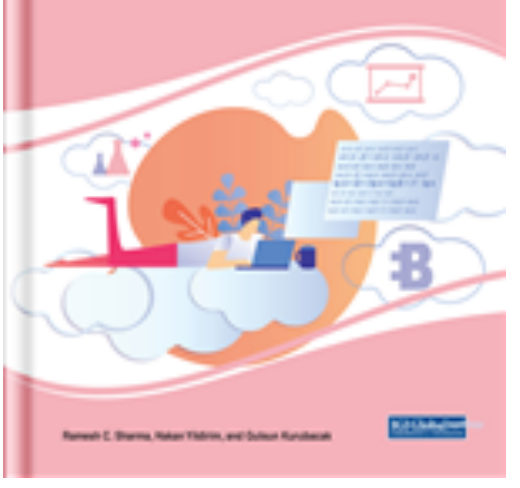

This book is edited by Ramesh Chander Sharma, Hakan Yildirim, Gulsun Kurubacak. The 1st edition of the book was published in 2020, IGI Global. The book has a total of 336 pages. The metadata of the book is as followings: ISBN13: 9781522594789, ISBN10: 1522594787, EISBN13: 9781522594796, and DOI: 10.4018/978-1-5225-9478-9.

First became popular with Nakamoto's (2008) seminal paper, Bitcoin: A Peer-to-Peer Electronic Cash System, blockchain technology aroused a lot of attention. Blockchain is an online decentralized and distributed ledger technology that has the ability to keep and track records in a safe, verifiable, and transparent manner. Bozkurt (2018, p. 104) summarises blockchain technology as follows: Blockchain technology is a distributed and cognitive record book and it can be defined as a new generation, global and decentralised infrastructure or mechanism. Blockchain technology first came up with bitcoins and has been used in various fields including education due to the superiorities it ensures, and as reported Sharples et al. (2016), it has great potential to be used in educational processes. 


\section{About the Book}

The edited book entitled Blockchain Technology Applications in Education has a total of 14 chapters. It mainly covers issues on blockchain technology and its applications in lifelong learning, higher education, open and distance learning. It also discusses virtual identity in blockchain, the strategy and management of blockchain in social transformation, and blockchain-based academic certificate management.

The first chapter, authored by Bozkurt and Ucar (2020), is entitled Blockchain Technology as a Bridging Infrastructure Among Formal, Non-Formal, and Informal Learning Processes. The chapter suggests that blockchain technology has the potential to link different modes of the educational process, and therefore, promises a lot for lifelong learning. Different modalities of learning (formal, non-formal, informal), blockchain technology, and its current use in educational processes are also explained. The authors suggest, based on the findings, that blockchain technology can be used to connect and interlink different educational experiences that occur in different educational modalities, enabling us to evaluate educational processes holistically and thus promote lifelong learning through the use of cutting-edge technologies.

The second chapter, authored by Mikroyannidis, Third, Domingue, Bachler and Quick (2020), is entitled Blockchain Applications in Lifelong Learning and the Role of the Semantic Blockchain. Blockchain's debut assures to transform both lifelong learning and the financial world in many ways. This chapter looks into the various aspects of lifelong learning which are affected by this new paradigm and describes an ecosystem in which the learner is at the centre of the learning process and its associated data. What is also discussed in this chapter are the possibilities that will be afforded by the combination of trustworthy educational data enhanced with meaningful web-accessible linked data, and what these developments will mean for learners, educators, and the employment market.

The third chapter, authored by Ciftci (2020), is entitled Change of the Learning Cycle After Blockchain: Chaining Trust Society. This chapter aims to create a foresight related to the role of using blockchain to meet the learning needs and how it may change the learning cycle in the 21 st century. The author first gives an explanation of the development of digital learning by describing the paradigm changes in lifelong learning activities. The author also explains the learning needs of the 21 st century within the framework of constructivism and connectivism in 
terms of changes in learning tendencies. The problems encountered in the new learning tendencies were examined in the context of critical theory. A definition of blockchain is also provided to determine how it can respond to problems in learning. The areas where blockchain can be used and the innovations it can bring to the field are interpreted. In the end, the author synthesizes learning and blockchain issues, and discusses how these can be used in learning applications, and how they can respond to learning needs.

The fourth chapter, authored by Bittencourt, Goedert, Sharma and Bortolozzi (2020), is entitled Framework Blockchain Education: Rupture in Higher Education. In this chapter, the authors point out the higher education sector, which needs to go beyond the pedagogical and material limits in order to give to the student the protagonism of his/her life story. They provide a definition of the word "rupture", which means to abstract the methods and models for living together in an environment of strong interactions and relationships, whose transactional cost becomes evident. Thereupon, this chapter presents a framework in an ecosystem of changes, feeds, analyses, diagnostics, and intelligence, which contributes to the formation of the student according to his/her expectations, that is, to contribute in an effective manner in his/her achievement, while offering a sustainable education.

The fifth chapter, authored by Hussain and Cakir (2020), is entitled Blockchain Technology in Higher Education: Prospects, Issues, and Challenges. This chapter explains the potentials of blockchain technologies in higher education along with its issues and challenges and provides detailed explanations and reasons for that. In sum, the authors state that blockchain stems in decentralization and distributed learning with characteristics of permanence of records, pursuit and transfer of knowledge, authority of institutions, and reliability of teaching and learning. So these characteristics of blockchain attract educational institutions, particularly the higher education institutions, to adopt it; however, despite all the potential and benefits of blockchain technology, the higher education stakeholders currently seem to be less aware of the social benefits and educational/ instructional potential of blockchain technology. The authors claim that blockchain technology can be addressed through proper advocacy and campaign.

The sixth chapter, authored by Sousa and Machado (2020), is entitled Blockchain Technology Reshaping Education: Contributions for Policy. The aim of this chapter, which is an 
exploratory study which focused on blockchain technology applied to European Union education policy, is to analyse the potentials of blockchain in education. To achieve this goal, a bibliometric analysis was conducted in order to identify studies already done on blockchain applied to education, and the main research items studied and how they can contribute to policy definition. The research question of this study is: What kind of contributions for policy emerge from the research that has been made on blockchain in education? The main findings are focused on getting a diploma, on the assessment, and the formative evaluation, but also related to the learning process in a distributive way to facilitate the educational management process.

The seventh chapter, authored by Kant (2020), is entitled Blockchain: A Resource of Competitive Advantage in Open and Distance Learning System. This chapter is an exploratory study that considers blockchain as a resource of competitive advantage for ODL system. The author also explains the relation between blockchain technology and the ODL system, states the opportunities and potential risks of embracing blockchain in ODL, yet also mentions the advantage by enhancing capabilities of combining resources. The significance of the chapter will be for the professionals, policymakers, researchers, governments, and regulators.

The eighth chapter, authored by Sathler (2020), is entitled For an Open Innovation Platform Dedicated to Education: A Blockchain Approach. In this chapter the author focuses on the innovation ecosystem dedicated to education in Brazil and argues that it has been strengthened, but it is still far short of the needs of society and the potential that technology brings. The author also states that the imperative of transformation is articulated by urgency and by the comprehensiveness and that Brazil's strategy of public financing to education would include new edtech products and services previously tested, validated, and priced by reverse auction made available in a national marketplace. It is also claimed that each municipality or school would be able to define its priorities for the acquisition of technology products and services and any software developed or made available by this open innovation platform should follow the guidelines of a free software. The author also claims that the training of teachers, managers, and staff would be an obligatory part of the adhesion, being primarily online. Moreover, students and their families would also be included as potential users by a blockchain approach. 
The ninth chapter, authored by Tugtekin, Dursun and Ugur (2020), is entitled Virtual Identity in Blockchain. In this chapter the authors focus mainly on virtual identity in blockchain. They claim that a blockchain-based virtual identity is no longer a really different identity today; instead, it now has a form that allows individuals to produce and manage their virtual identities and facilitates their lives. In addition, its usage potential has led to the use of blockchain for institutional purposes, and so it is now possible for institutions to interact with their stakeholders via their institutional virtual identities. The authors also state that virtual identities play an important facilitator role in communication to be established by educational institutions with their students especially at higher education level.

The tenth chapter, authored by Rodrigues, Franco, Scheid, Kanhere and Stiller (2020), is entitled A Technology-driven Overview on Blockchain-based Academic Certificate Handling. What is discussed in this chapter are the main proposals toward the handling of academic certificates from a technological point of view and the technical aspects that may influence the relationship between confidentiality and transparency as well as application requirements such as performance and reliability in contrast to the blockchain characteristics. The chapter also sums up the key challenges and opportunities based on this discussion that outline future directions for academic certificate management.

The eleventh chapter, authored by Moraes (2020), is entitled Blockchaining Corporate Education. In this chapter, the author states that all of remarks of Roger Deacon, who is researching the relevance and implications of the work of Michel Foucault for education, lead to concerns about the idea of blockchain for corporate education. The reason for this is that the life of an individual may be registered from the very beginning throughout the whole educational system. The author questions how one should think about corporate education in a scenario in which even computer-driven choices are biased and even the peer-to-peer system with a blockchain system may be circumvented. And finally, the author suggests that so as to keep a corporate performing well, the multiple skills of collective games could indicate the need for multiple intelligences.

The twelfth chapter, authored by Nery, Macambira, Mota and Rezende (2020), is entitled Social Media, Cyberculture, Blockchains, and Education: A New Strategy for Brazilian Higher Education. This chapter aims to contribute to the debate of the uses of social media, cyberculture, and blockchain technology for the development of educational strategies. 
Therefore, it reviews the existing scientific literature on social networking, social media, cyberculture, and blockchains related to Brazil. The chapter focuses on Brazil because higher education in Brazil has taken a significant turn recently with the substantial reductions of government investments in social justice policies.

The thirteenth chapter, authored by Altinay Aksal, Bicen and Altinay Gazi (2020), is entitled Blockchain Strategy and Management in Social Transformation for Being Social Agents. This chapter promotes the virtues of new learning and teaching by having a closer look at educational technology. Transformation becomes a crucial attempt for social changes and development, so the practice of online education and reflections clarify being a social agent and make an innovation in pedagogy. This chapter also emphasizes the transition and quality framework and the role of blockchain strategy and management and strategies and policies in establishing social agents for the diffusion and development of equality and access, openness in education.

The fourteenth chapter, authored by Mahankali and Chaudhary (2020), is entitled Blockchain Education: A Comprehensive Approach. The authors examine the usefulness of blockchain technology-led digitization, automation of trust, and disintermediation in the education sector in this chapter. They explore some of the remarkable use cases and challenges that are encountered by blockchain technology. They also study the current state of blockchain technology-enabled applications in related domains and its implications for the education sector in India along with a real-life illustration with implementation using AuxCert on Auxledger, a permissioned blockchain platform from Auxesis group.

\section{Conclusion and Suggestions}

Blockchain Technology Applications in Education is an essential book for researchers, academicians, curriculum designers, instructional designers, IT consultants, administrators, researchers, and students might benefit from this book because it includes a variety of topics such as new management models, communicational actions, pedagogical approaches, new technologies, and evaluation models, and it examines how open universities establish a blockchain network for decentralized learning. The chapters provide plenty of information about these issues, state possible challenges and offer solutions to them, all of which enlighten the readers as well as provoke further thought. In the future version of the book, applied 
researches might be focused on so as to perceive the opportunities created by the blockchain technology and to develop a policy.

\section{About the Author(s)}

Aylin Ceylan

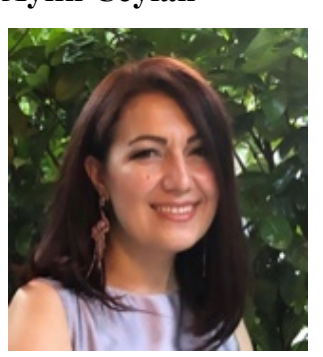

Aylin Ceylan is an instructor of English Language at Anadolu University, School of Foreign Languages, Turkey. She holds a BA in English Language and Literature from Hacettepe University, and ICELT and CELTA granted by Cambridge University. She is currently attending MA in distance education. She is interested in artificial intelligence, learner needs and differences, learner motivation, and learner support systems.

Mailing Address: Anadolu University, Eskişehir, Turkey.

E-mail: aylinceylan@anadolu.edu.tr

\section{REFERENCES}

Altinay Aksal, F., Bicen, H., \& Altinay Gazi, Z. (2020). Blockchain Strategy and Management in Social Transformation for Being Social Agents. In R. Sharma, H. Yildirim, \& G. Kurubacak (Eds.), Blockchain Technology Applications in Education (pp. 260-266). Hershey, PA: IGI Global. doi:10.4018/978-1-5225-9478-9.ch013

Bozkurt, A. (2018). Online networks, distributed learning and blockchain technology. In Proceedings of EDUCCON 2018: Education 4.0 Studies (pp. 102-109). Ankara, Turkey: Academic Press.

Bozkurt, A., \& Ucar, H. (2020). Blockchain Technology as a Bridging Infrastructure Among Formal, Non-Formal, and Informal Learning Processes. In R. Sharma, H. Yildirim, \& G. Kurubacak (Eds.), Blockchain Technology Applications in Education (pp. 1-15). Hershey, PA: IGI Global. doi:10.4018/978-1-5225-9478-9.ch001

Ciftci, G. T. (2020). Change of the Learning Cycle After Blockchain: Chaining Trust Society. In R. Sharma, H. Yildirim, \& G. Kurubacak (Eds.), Blockchain Technology Applications in Education (pp. 42-79). Hershey, PA: IGI Global. doi:10.4018/978-1-5225-94789.ch003

Falcão de Bittencourt, D., Goedert, A. R., Sharma, R. C., \& Bortolozzi, F. (2020). Framework Blockchain Education: Rupture in Higher Education. In R. Sharma, H. Yildirim, \& G. Kurubacak (Eds.), Blockchain Technology Applications in Education (pp. 80-96). Hershey, PA: IGI Global. doi:10.4018/978-1-5225-9478-9.ch004 
Hussain, I., \& Cakir, O. (2020). Blockchain Technology in Higher Education: Prospects, Issues, and Challenges. In R. Sharma, H. Yildirim, \& G. Kurubacak (Eds.), Blockchain Technology Applications in Education (pp. 97-112). Hershey, PA: IGI Global. doi:10.4018/978-1-5225-9478-9.ch005

Kant, N. (2020). Blockchain: A Resource of Competitive Advantage in Open and Distance Learning System. In R. Sharma, H. Yildirim, \& G. Kurubacak (Eds.), Blockchain Technology Applications in Education (pp. 127-152). Hershey, PA: IGI Global. doi:10.4018/978-1-5225-9478-9.ch007

Mahankali, S., \& Chaudhary, S. (2020). Blockchain in Education: A Comprehensive Approach - Utility, Use Cases, and Implementation in a University. In R. Sharma, H. Yildirim, \& G. Kurubacak (Eds.), Blockchain Technology Applications in Education (pp. 267-293). Hershey, PA: IGI Global. doi:10.4018/978-1-5225-9478-9.ch014

Mikroyannidis, A., Third, A., Domingue, J., Bachler, M., \& Quick, K. A. (2020). Blockchain Applications in Lifelong Learning and the Role of the Semantic Blockchain. In R. Sharma, H. Yildirim, \& G. Kurubacak (Eds.), Blockchain Technology Applications in Education (pp. 16-41). Hershey, PA: IGI Global. doi:10.4018/978-1-5225-94789.ch002

Moraes, R. B. (2020). Blockchaining Corporate Education. In R. Sharma, H. Yildirim, \& G. Kurubacak (Eds.), Blockchain Technology Applications in Education (pp. 224-241). Hershey, PA: IGI Global. doi:10.4018/978-1-5225-9478-9.ch011

Nakamoto, S. (2008). Bitcoin: A Peer-to-Peer Electronic Cash System. Retrieved from www.bitcoin.org

Nery, M. B., Macambira, M. O., Mota, M. F., \& Rezende, I. C. (2020). Social Media, Cyberculture, Blockchains, and Education: A New Strategy for Brazilian Higher Education. In R. Sharma, H. Yildirim, \& G. Kurubacak (Eds.), Blockchain Technology Applications in Education (pp. 242-259). Hershey, PA: IGI Global. doi:10.4018/978-15225-9478-9.ch012

Rodrigues, B., Franco, M. F., Scheid, E., Kanhere, S. S., \& Stiller, B. (2020). A Technologydriven Overview on Blockchain-based Academic Certificate Handling. In R. Sharma, H. Yildirim, \& G. Kurubacak (Eds.), Blockchain Technology Applications in Education (pp. 197-223). Hershey, PA: IGI Global. doi:10.4018/978-1-5225-9478-9.ch010

Sathler, L. (2020). For an Open Innovation Platform Dedicated to Education: A Blockchain Approach. In R. Sharma, H. Yildirim, \& G. Kurubacak (Eds.), Blockchain Technology 
Applications in Education (pp. 153-169). Hershey, PA: IGI Global. doi:10.4018/978-15225-9478-9.ch008

Sharples, M., de Roock , R., Ferguson, R., Gaved, M., Herodotou, C., Koh, E., KukulskaHulme, A., Looi, C-K, McAndrew, P., Rienties, B., Weller, M., Wong, L. H. (2016). Innovating Pedagogy 2016: Open University Innovation Report 5. Milton Keynes: The Open University.

Sousa, M. J., \& Machado, A. D. (2020). Blockchain Technology Reshaping Education: Contributions for Policy. In R. Sharma, H. Yildirim, \& G. Kurubacak (Eds.), Blockchain Technology Applications in Education (pp. 113-125). Hershey, PA: IGI Global. doi:10.4018/978-1-5225-9478-9.ch006

Tuğtekin, E. B., Dursun, Ö. Ö., \& Uğur, S. Ş. (2020). Virtual Identity in Blockchain. In R. Sharma, H. Yildirim, \& G. Kurubacak (Eds.), Blockchain Technology Applications in Education (pp. 171-196). Hershey, PA: IGI Global. doi:10.4018/978-1-5225-94789.ch009 